\title{
Remote ion-pair interactions in Fe-porphyrin-based molecular catalysts for the hydrogen evolution reaction
}

\author{
Sitthichok Kasemthaveechok, ${ }^{a}$ Bruno Fabre, ${ }^{a}$ Gabriel Loget*a and Rafael Gramage-Doria*a \\ The environmentally benign production of clean energies is extremely important for the sustainable progress of our society. \\ In this respect, dihydrogen $\left(\mathrm{H}_{2}\right)$ has been considered in the last decades as an efficient energy carrier and much effort has \\ been directed to the hydrogen evolution reaction (HER). Herein, we report on the efficiency of iron-based 5,10,15,20- \\ tetraphenylporphyrins containing carboxylate groups at different positions (ortho, meta and para of the meso-substituted \\ aryl groups of the porphyrin backbone) as molecular catalysts for the HER. The iron-based porphyrin containing the \\ carboxylic acids in ortho position was found completely inactive in HER. Furthermore, besides stereoelectronic control, the \\ subttle differences observed in the cyclic voltammograms (CV) as well as those associated to the electrocatalytic activity \\ might involve a previously neglected, ion-pair interaction between the carboxylate groups of the porphyrin scaffold and the \\ chloride anions belonging to the proton source, which highlights the relevance of ion-pair contacts remote from the active \\ center for this type of catalytic systems.
}

\section{Introduction}

The development of sustainable technologies for energy conversion is extremely important in the actual frame of global air pollution and climate change. Particular focus is currently given to solar-to-hydrogen $\left(\mathrm{H}_{2}\right)$ conversion, which seems very promising to decrease the ecological footprint of energy grids. ${ }^{1}$ In this approach, the sunlight is absorbed by a semiconductor junction and readily converted into a current that is applied to an electrolyte for water electrolysis. ${ }^{2}$ During the latter step, the chemical bonds of water are split up generating $\mathrm{H}_{2}$, an energydense fuel that can be readily stored and used to provide sustainable energy on site and on demand. ${ }^{3}$ To be efficient, solar-to- $\mathrm{H}_{2}$ conversion devices should be able to produce a high photoelectrocatalytic current with a low power input. The performance of these systems relies on electrocatalysts, which are essential components for decreasing the energy barrier as well as increasing the kinetics of water electrolysis halfreactions (hydrogen evolution reaction -HER- and oxygen evolution reaction -OER-). ${ }^{4}$ Because the best electrocatalysts known so far for HER are traditionally derived from scarce and expensive materials ( $\mathrm{Pt}, \mathrm{Pd}, \mathrm{Rh}$ ), a considerable amount of research effort currently goes into the fundamental understanding of HER and the development of more efficient and low-cost electrocatalysts. ${ }^{5}$ In this context, well-defined organometallic molecules based on abundant metals are unique models for the study of HER. Indeed, they can be

\footnotetext{
a. Univ Rennes, CNRS, ISCR-UMR 6226, F-35000 Rennes, France. E-mail: gabriel.loget@univ-rennes1.fr, rafael.gramage-doria@univ-rennes1.fr Electronic Supplementary Information (ESI) available: Detailed experimental procedures; physical and chemical characterizations and analysis. See DOI: $10.1039 / \times 0 \times x 00000 x$
}

precisely tailored in order to change the local environment of the active metal centre and, as such, it enables to control the catalytic activity. ${ }^{6}$ Several HER-active organometallic compounds based on abundant metals have been reported. ${ }^{7}$ Among them, $\mathrm{Co},{ }^{8} \mathrm{Fe}^{9}{ }^{9} \mathrm{Ni}^{10}$ and $\mathrm{Sb}^{11}$ porphyrins are particularly appealing (Fig. 1) because of (1) their rigid, planar and stable geometry, (2) the ease of synthetic modification ${ }^{6 b}$ as well as (3) their potential for electrode integration. ${ }^{12}$ The multiple benefits that arise from the unique structure of the porphyrin ring towards HER have been highlighted by several groups. For instance, Cao et al. have described the positive influence of electron withdrawing groups $\left(-\mathrm{C}_{6} \mathrm{~F}_{5}\right)$ attached to the nickel- and gallium-porphyrin ring, respectively (A, Fig. 1). ${ }^{13}$ Zhang et al. have shown that a $\beta$-hydrogenated porphyrin ring increases the electron density on the metal centre, thus increasing its reactivity as well (B, Fig. 1). ${ }^{14}$ Nocera et al. have demonstrated the possibility of introducing a "hangman" covalently-linked acid functionality on the second coordination sphere to act as a proton relay at the proximity of the metal center (C, Fig. 1). ${ }^{15}$ So far, the study of electrocatalytic iron porphyrins bearing multiple proton relays and local proton sources have been limited to oxygen reduction reaction (ORR) ${ }^{16}$ and $\mathrm{CO}_{2}$ reduction. ${ }^{17}$ In this contribution, we report a systematic study of iron porphyrins bearing carboxyl functionalities (as acids and as esters at different positions) that behave as molecular catalysts for HER (2-4 and 2'-4', Fig. 1). The acid-containing catalysts were found to be generally more efficient than their corresponding esters in terms of activity. Such observations for HER might involve a previously neglected, ion-pair network between the catalyst and the proton source. 


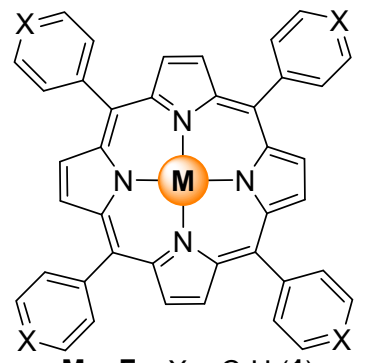

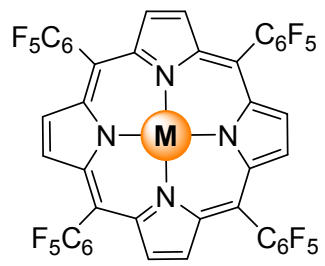

$\mathrm{M}=\mathrm{Ni}, \mathrm{Ga}(\mathrm{A})$

$$
\begin{aligned}
& M=F e, X=C-H(1) \\
& M=\text { Co, } X=N-M e
\end{aligned}
$$

$\mathbf{M}=\mathbf{S b}, X=\mathrm{C}-\mathrm{Me}$

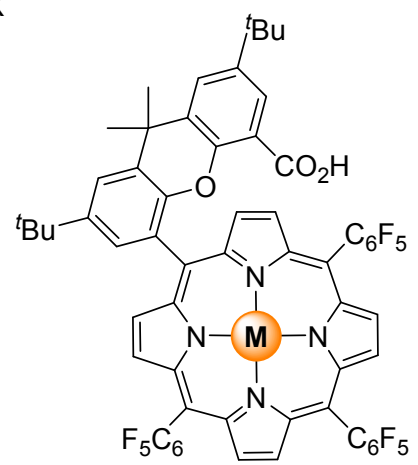

(B)

$\mathrm{M}=\mathrm{Ni}, \mathrm{Co}(\mathrm{C})$

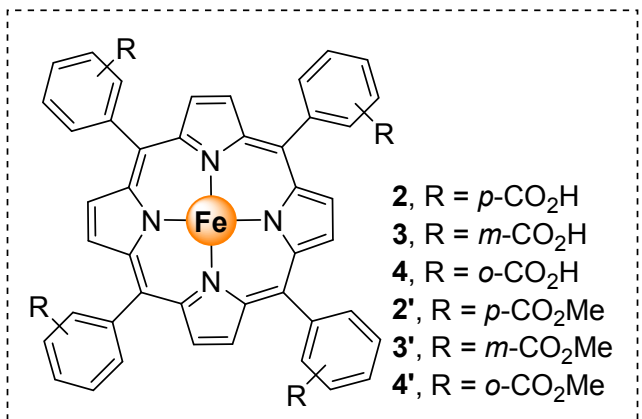

Fig. 1. Molecular structures of HER-relevant electrocatalysts derived from porphyrins based on earth-abundant metals (1, A, B and $\mathbf{C})^{8-15}$ and iron-based porphyrins employed in this study (framed) containing carboxylic acids (2-4) and its corresponding methyl ester derivatives (2'-4').

\section{Results and discussion}

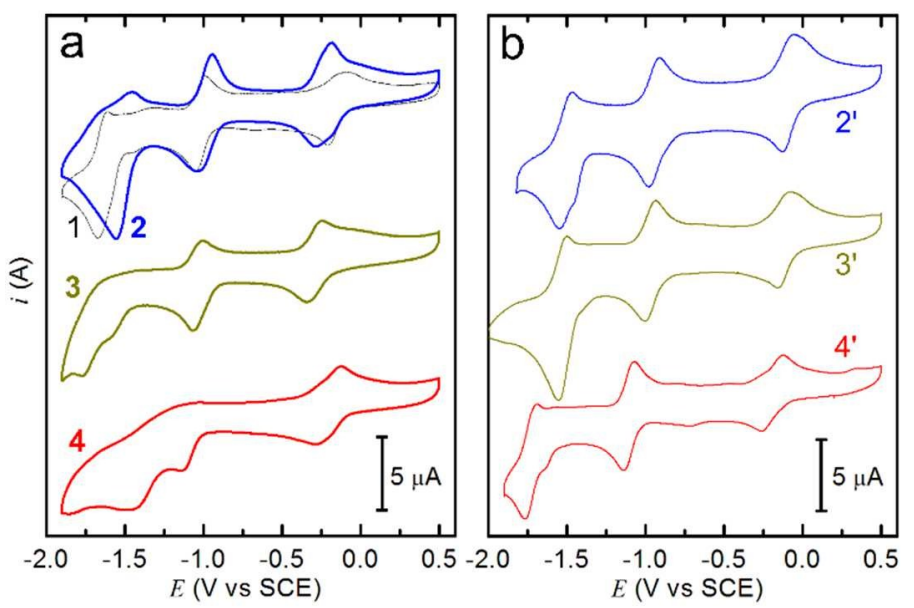

Fig. 2. CVs obtained for the iron porphyrins containing carboxylic acids 2-4 (a) and methyl esters 2'-4' (b). The CV of benchmark compound $\mathbf{1}$ is represented by a black thin line (a).
The iron-containing porphyrins 1-4 and 2'-4' were prepared according to slight modifications from literature procedures (see Experimental section and ESI). Next, we studied the cathodic behavior of all the iron porphyrins (Fig. 2a-b). Iron porphyrin 1 was chosen as a reference since its electrochemistry and HER activity are well documented. ${ }^{9}$ Except for 4 , the cyclic voltammograms (CVs) of all the iron porphyrins in $\mathrm{N}, \mathrm{N}$-dimethylformamide (DMF) as solvent show an electrochemical response comparable to 1 , that is, with two quasi-reversible redox waves at $E>-1.30 \mathrm{~V}$ vs $\mathrm{KCl}$-saturated calomel electrode (SCE) which are attributed to the redox couples $\mathrm{Fe}^{\prime \prime \prime}\left(\right.$ porphyrin) ${ }^{+} / \mathrm{Fe}^{\prime \prime}\left(\right.$ porphyrin) $\left(E\left(\mathrm{Fe}^{\mathrm{III}} / \mathrm{Fe}^{\mathrm{II}}\right)^{0^{\prime}}=-0.25 \pm\right.$ $0.04 \vee$ for 2-4 and $-0.12 \pm 0.03 \vee$ for 2'-4') and

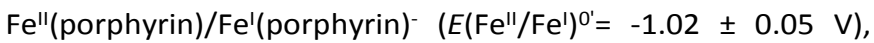
respectively. At more negative potentials $(E<-1.30 \mathrm{~V})$, another cathodic wave, which is less reversible than the two first ones, was observed for $\mathbf{2}$ and the three ester derivatives $\mathbf{2}^{\prime}-\mathbf{4}$ '. This wave is attributed to the reduction of $\mathrm{Fe}^{\prime}$ (porphyrin) to $\mathrm{Fe}^{0}$ (porphyrin) ${ }^{2-}$, that is, the catalytically active species for $\mathrm{HER}^{9}$ and $\mathrm{CO}_{2}$ reduction. ${ }^{12 \mathrm{~b}} \mathrm{~A}$ peculiar behavior was observed for ortho-substituted tetraacid 4, which displayed only one clear quasi-reversible wave (Fe"l'/Fe") at $-1.46 \mathrm{~V}$ (vide infra), the two subsequent cathodic waves ( $\mathrm{Fe}^{\prime \prime} / \mathrm{Fe}^{\mathrm{l}}$ and $\mathrm{Fe}^{l} / \mathrm{Fe}^{0}$ ) being clearly much less reversible (the scan rate dependency on the reversibility for this compound is described below).

Next, all iron porphyrins were tested for $\mathrm{HER}$ with $\mathrm{Et}_{3} \mathrm{NHCl}$ serving as a proton source (Fig. S2 shows the HER activity for $\mathbf{1}$, see ESI). As shown in Fig. 3a-f, the third redox wave was affected by the presence of acid for all the iron porphyrins except for 4 . In these cases, $\mathrm{Et}_{3} \mathrm{NHCl}$ induced an increase of the reduction current as well as a loss of reversibility for the methyl ester derivatives 2'-4'. The reduction wave was exclusively dependent on the acid concentration in the 1 to $15 \mathrm{mM}$ concentration range. These effects are indicative of an electrochemical catalysis, and demonstrate that compounds 2 $\mathbf{3}$ and ' '-4' are catalytically active for HER (vide infra). The HERactive compounds triggered the catalysis with onset potentials comprised between $-1.28 \mathrm{~V}$ and $-1.43 \mathrm{~V}$; and maximum current densities in the order of $1 \mathrm{~mA} \mathrm{~cm}{ }^{-2}$, the highest being measured for the carboxylic acids $\mathbf{2}$ and $\mathbf{3}$ (Fig. 4a-b). It is worthy to mention that in terms of onset potential, the best catalyst was 2', which is in good agreement with the fact that it exhibited the least negative $\mathrm{Fe}^{\prime}$ (porphyrin)- reduction wave (Fig. 2b). The ortho derivatives (4 and 4') showed a notably different behavior for HER with respect to all other iron porphyrins (Fig. 3a-f). While 4' exhibited the lowest onset potential (<-1.4 V, Fig. 4b), the CVs measured for $\mathbf{4}$ did not change significantly upon addition of $\mathrm{Et}_{3} \mathrm{NHCl}$ (Fig. 3c), revealing its total inactivity towards HER. In contrast with the meta- and the parasubstituted iron porphyrins, the ortho- ones might lead to an important constrained geometry which could result in a weaker electronic stabilization of the reduced states of the catalyst and thus more cathodic redox waves. This is clearly revealed by the $\mathrm{CV}$ of 4', which shows the three redox waves at slightly more negative potentials compared to the other ester derivatives $\mathbf{2}^{\prime}$ and 3' (Fig. 2b). This effect explains the low reduction potential of $\mathrm{Fe}^{1}$ (porphyrin)- to $\mathrm{Fe}^{0}$ (porphyrin) ${ }^{2-}$ as well as the low catalytic 
HER onset potential for $4^{\prime}$ (Fig. $3 f$ and $4 b$ ). In contrast, the atypical behavior of $\mathbf{4}$ regarding its $\mathrm{CV}$ and its inactivity towards HER must be different and was further assessed.
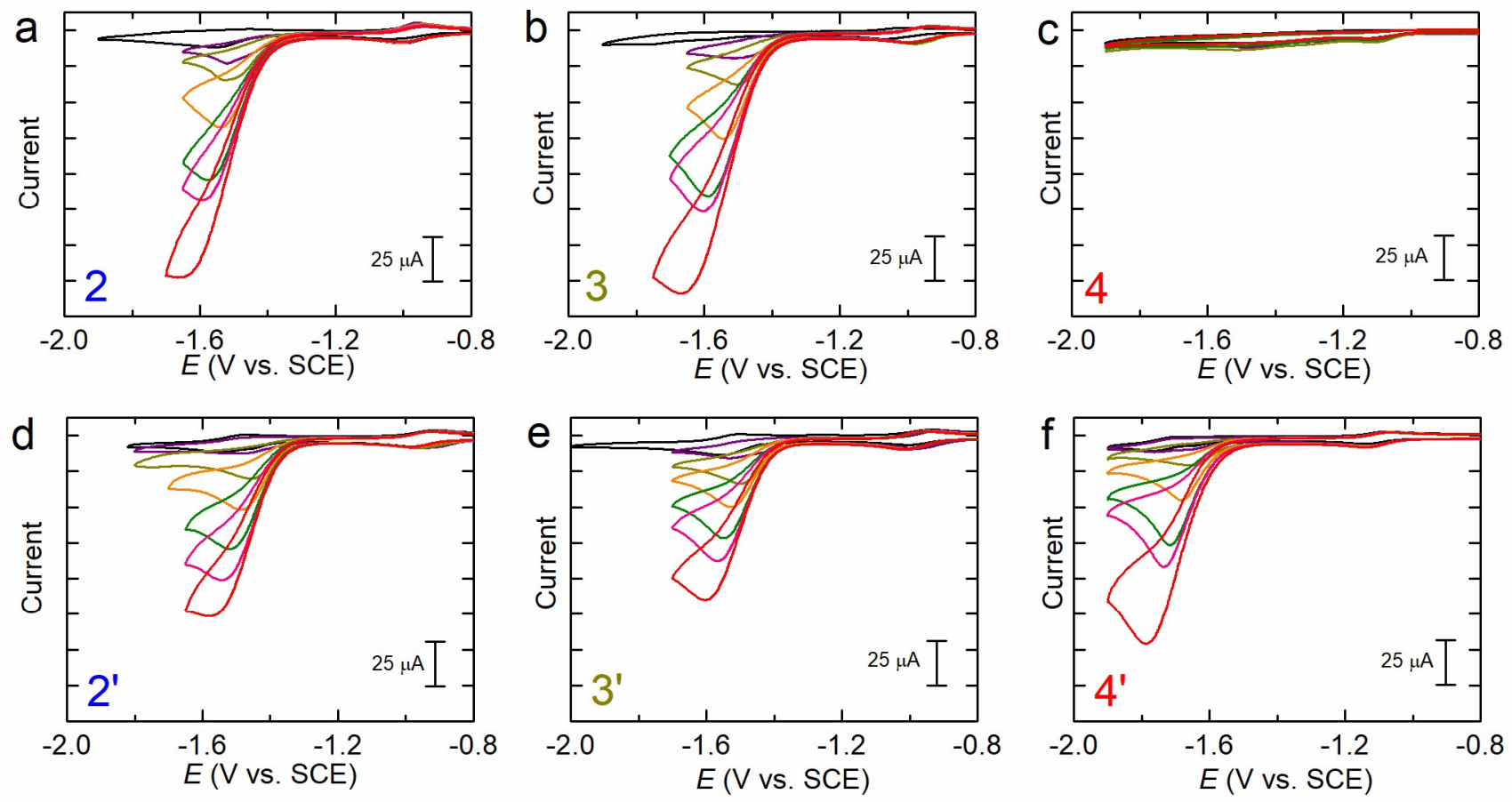

Fig. 3. Cyclic voltammograms of $\mathbf{2}$ (a), 3 (b), 4 (c), 2' (d), 3' (e) and 4' (f) (0.5 mM) in the presence of 0 mM (black), 1 mM (purple), $2.5 \mathrm{mM}$ (dark brown), $5 \mathrm{mM}$ (orange), $7.5 \mathrm{mM}$ (green), $10 \mathrm{mM}$ (pink) and $15 \mathrm{mM}$ (red) of $\mathrm{Et}_{3} \mathrm{NHCl}$ in $\mathrm{DMF}\left(0.1 \mathrm{M}^{2}\left[\mathrm{Bu}_{4} \mathrm{~N}^{+}\right]\left[\mathrm{PF}_{6}^{-}\right]\right)$at $100 \mathrm{mV} \mathrm{s}^{-1}$.

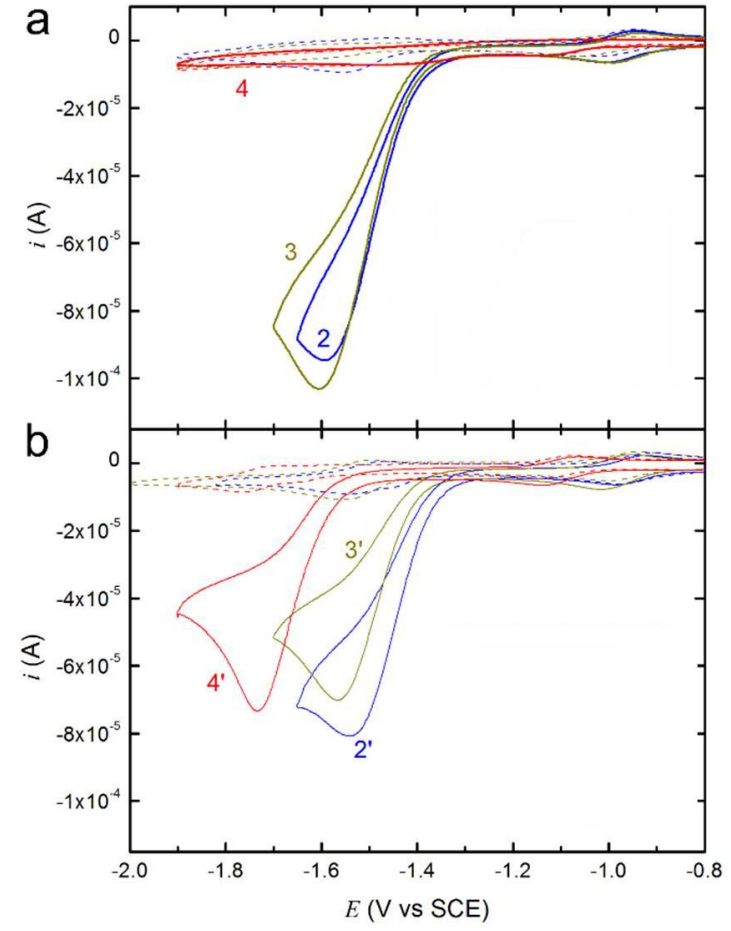

Fig. 4. CVs showing the cathodic behaviour of iron porphyrins alone (dashed lines) and in the presence of $10 \mathrm{mM} \mathrm{Et}_{3} \mathrm{NHCl}$ (straight lines). a) For the carboxylic acid series (2-4) and b) for the methyl ester series (2'-4').
The two most negative reduction waves for $\mathbf{4}$ were examined as a function of the potential scan rate $v$ in the absence of a proton source. The Fe"(porphyrin)/Fe'(porphyrin)wave was electrochemically reversible (Fig. S7-S10 in the ESI) with an apparent electron-transfer standard rate constant $k_{\mathrm{s}}$ of ca. $0.06 \mathrm{~cm} \mathrm{~s}^{-1}$ (Table S2 in the ESI). The most negative wave, assigned to the $\mathrm{Fe}^{\prime}\left(\right.$ porphyrin) $/ / \mathrm{Fe}^{\mathrm{O}}$ (porphyrin) ${ }^{2-}$ couple exhibited a one-electron irreversible cathodic peak at low scan rates. At high scan rates $\left(>10 \mathrm{~V} \mathrm{~s}^{-1}\right)$, a partial reversibility appears for this system (Fig. S8 in the ESI) and a value of $k_{\mathrm{s}}$ identical to that calculated for Fe"(porphyrin)/Fe'(porphyrin)was determined from the peak-to-peak separation. To sum-up, the electrochemical data obtained for $\mathrm{Fe}^{\prime}$ (porphyrin) $/ \mathrm{Fe}^{\mathrm{O}}$ (porphyrin) ${ }^{2-}$ in $\mathbf{4}$ is consistent with a EC mechanism consisting of an reversible electrochemical step (E) followed by an irreversible chemical step (C). ${ }^{18}$ The irreversible chemical step in $\mathbf{4}$ could be attributed to the interference of chloride ions between the iron-hydride active species and the carboxylic acid group, as supported by molecular modelling (Fig. S18 in the ESI) or by the formation of a Fe-oxo bridge, both explaining the unconventional CV shape as well as the inhibition of HER.

Although it is difficult to exclude any proton relay in the ironporphyrins 2-4 at this stage, it seems unlikely because (i) the carboxylic acid functionalities in $\mathbf{2}$ and $\mathbf{3}$ are located rather far apart from the iron center when compared to the designs by Nocera ${ }^{1 a, 2 d, 10,15,19 b}$ and DuBois ${ }^{6 a, 7 b}$ and (ii) iron-porphyrin 4 which is the one that contains the carboxylic acid functionalities 
closest to the iron center is completely inactive in HER (Fig. 3c). It is important to note that the differences observed in HER between the ester-containing iron-porphyrins 2', 3' and 4' might be a consequence of the different electronic properties of the porphyrin ligand coordinated to the iron center in each case.

To evaluate the efficiency of the iron catalysts towards HER, pseudo-first-order rate constants $\left(k_{o b s}\right)$ were calculated as a function of the concentration of $\mathrm{Et}_{3} \mathrm{NHCl}$ using the following relation:

$$
k_{o b s}=\left(\frac{i_{c}}{i_{p}} \cdot 0.223\right)^{2} \cdot \frac{F v}{R T}
$$

Where $i_{\mathrm{c}}$ is the catalytic peak current, $i_{\mathrm{p}}$ is the non-catalytic peak current, $R$ is the ideal gas constant, $T$ equals $298.15 \mathrm{~K}, F$ is the Faraday's constant, and $v$ is the scan rate.
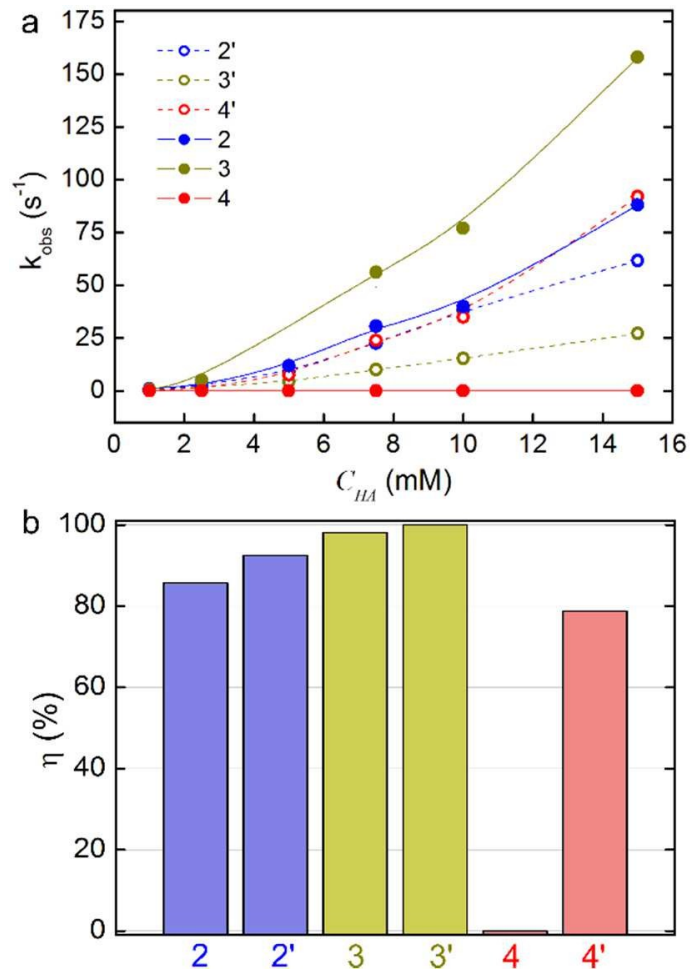

Fig. 5. a) Evolution of $k_{\mathrm{obs}}$ for the iron porphyrins as a function of the concentration of $\mathrm{Et}_{3} \mathrm{NHCl}$. b) Faradaic efficiency of each iron porphyrin in the presence of $15 \mathrm{mM} \mathrm{Et}_{3} \mathrm{NHCl}$.

This model has been previously applied for measuring catalytic rates of first-order electrocatalytic reactions and HER; although the final mechanism might be more complicated. ${ }^{7 e, 14}$ In addition, we performed series of preparative-scale electrolysis in a Hoffman cell, which allowed measuring the quantity of produced $\mathrm{H}_{2}$ and determining the faradaic efficiencies $(\eta)$ for each iron porphyrin, which, except for 4 , all ranged from 79 to $100 \%$. Besides 4 and 4' that have a peculiar behavior (vide supra), the value of $k_{\text {obs }}$ (at a proton source concentration of 15 $\mathrm{mM})$ was significantly higher with the acid-containing porphyrins $2\left(88 \mathrm{~s}^{-1}\right)$ and $3\left(158 \mathrm{~s}^{-1}\right)$ than with their corresponding esters $2^{\prime}\left(61 \mathrm{~s}^{-1}\right)$ and $3^{\prime}\left(27 \mathrm{~s}^{-1}\right)$, highlighting the importance of a remotely located acid group for HER. Interestingly, the presence of the proton source in solution did not influence the position of the two first redox waves for the ester derivatives 2' and 3' (see details in Fig. S3), whereas it induced anodic shifts for all redox waves of acid-containing 2 and $\mathbf{3}$ (see details in Fig. S4). This behavior is quite unexpected as cathodic shifts are typically expected to occur in the presence of chloride. ${ }^{22}$ The same behavior was observed when using other protons sources such as $\mathrm{NH}_{4} \mathrm{Cl}$ and $\mathrm{Me}_{3} \mathrm{NHCl}$ (see details in Fig. S5) but was much less pronounced with $\mathrm{NH}_{4} \mathrm{PF}_{6}$ (see Fig. S6). Since these two redox waves are Fe-centered one-electron reductions that do not involve proton transfer, the shifts are not caused by the presence of $\mathrm{H}^{+}$but rather reveal the noninnocence of the proton source and its interaction with the iron porphyrin.

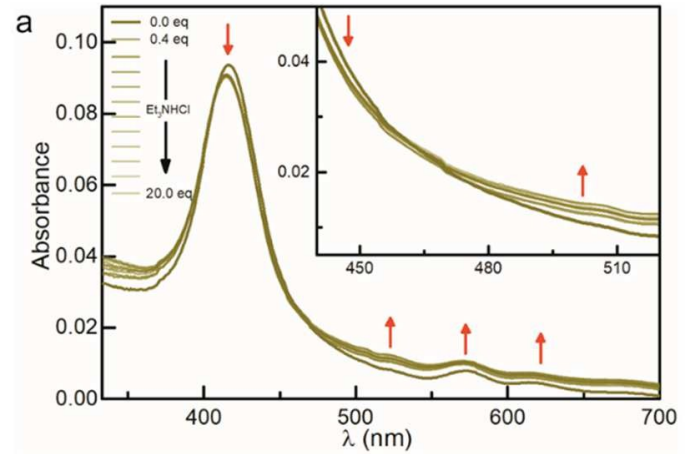

b

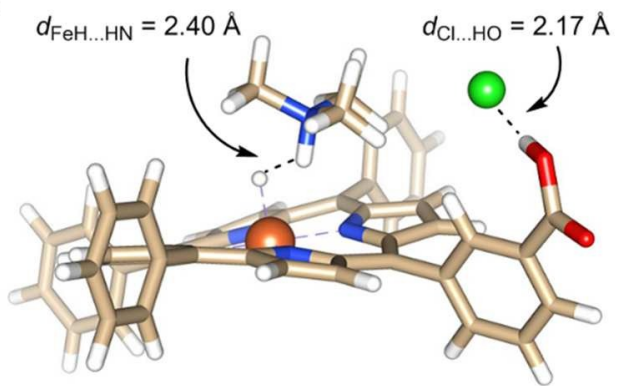

Fig. 6. a) UV-vis binding studies between 3 and $\mathrm{Et}_{3} \mathrm{NHCl}$ in DMF. b) $\mathrm{PM} 3-$ minimized self-assembly of $3^{*}$ with $\mathrm{Me}_{3} \mathrm{NHCl}$.

To address such hypothesis, UV-vis studies were performed by adding incremental amounts of a proton source $\left(\mathrm{Et}_{3} \mathrm{NHCl}\right)$ to solutions of iron porphyrins at a constant concentration (Fig. S11-S17 in the ESI). For all cases, significant changes were observed as compared to the background spectrum and isosbestic points were found (Fig. 6a and ESI). However, quantification of each binding event was not possible due to the multiple possibilities that can arise. Although qualitatively, these findings indicate a host-guest interaction between the proton source (guest) and the iron porphyrin (host) even in the presence of a strongly coordinating polar solvent, i.e. DMF. To better understand such interaction, preliminary PM3minimized calculations were carried out with the hydride derivative of an iron porphyrin containing one carboxylic acid in meta position $\left(3^{*}\right)$, which is a simplified model of the resting state of $\mathbf{3}$, that is the catalyst that displays the most interesting features towards HER. In the presence of a model of ammonium chloride $\left(\mathrm{Me}_{3} \mathrm{NHCl}\right)$ as the proton source, a supramolecular structure was found to be energetically stable where the chloride anion is hydrogen bonding with the carboxylic group of 
3* whereas the iron-hydride lies at close proximity of the ammonium cation (Fig. $6 \mathrm{~b}$ and Fig. S19 in the ESI). Consequently, it seems reasonable to consider that carboxylic acids, even if they are remote from the active site, interact with chloride ions at some extent, thus leaving the iron centre more reactive towards HER.

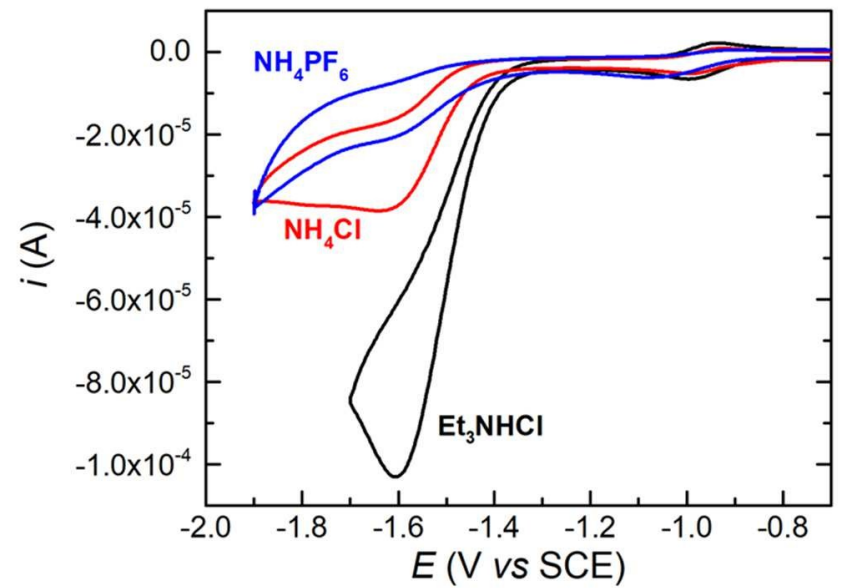

Fig. 7. $\mathrm{CVs}$ of $3(0.5 \mathrm{mM})$ in the presence of $10 \mathrm{mM} \mathrm{Et}_{3} \mathrm{NHCl}$ (black), $\mathrm{NH}_{4} \mathrm{Cl}$ (red) and $\mathrm{NH}_{4} \mathrm{PF}_{6}$ (blue) in DMF $(0.1 \mathrm{M}$ $\left.\left[\mathrm{Bu}_{4} \mathrm{~N}^{+}\right]\left[\mathrm{PF}_{6}^{-}\right]\right)$at $100 \mathrm{mV} \mathrm{s}^{-1}$.

This hypothesis was further stressed by electrochemical experiments where the $\mathrm{Cl}^{-}$anions were swapped by $\mathrm{PF}_{6}$ - anions. In Fig. 7 we compare the electrocatalytic activity obtained for $\mathbf{3}$ in the presence of the same concentration of different proton sources, namely, $\mathrm{Et}_{3} \mathrm{NHCl}, \mathrm{NH}_{4} \mathrm{Cl}$ and $\mathrm{NH}_{4} \mathrm{PF}_{6}$. First, one can observe that a higher catalytic current was obtained for $\mathrm{Et}_{3} \mathrm{NHCl}$, which can be understood by the lower pKa of $\mathrm{Et}_{3} \mathrm{NH}^{+}$ with respect to $\mathrm{NH}_{4}{ }^{+}$in DMF. ${ }^{28}$ Of particular interest, the comparison of the voltammograms obtained with $\mathrm{NH}_{4} \mathrm{Cl}$ and $\mathrm{NH}_{4} \mathrm{PF}_{6}$ show that the replacement of $\mathrm{Cl}^{-}$by a bulky anion $\left(\mathrm{PF}_{6}-\right.$ ), results in HER inhibition, highlighting again the importance of the chloride anion for promoting HER with the carboxylatecontaining tetraphenylporphyrins.

\section{Conclusions}

In summary, we have shown that iron-based porphyrins bearing carboxylic groups are suitable molecular electrocatalysts for HER when the substituents are located sufficiently far away from the Fe centre, as it is the case for $\mathbf{2}$ and $\mathbf{3}$. A combination of complementary studies including $\mathrm{CV}$, kinetics, bulk electrolysis, UV-vis spectroscopy and preliminary molecular modelling together suggested a unique ion-pair interaction between the molecular catalyst and the proton source as a key feature for these systems. Such interactions, which are prevalent in nature, ${ }^{20}$ might be exploited for the overall water splitting reaction. Further studies will have to be devoted to unravel the real mechanistic pathway (heterolytic vs. homolytic) operating in this particular class of iron-based porphyrins ${ }^{21}$ as well as the exact kinetic role of the chloride anions. ${ }^{22}$

\section{Experimental}

\subsection{General methods}

All manipulations were carried out in a dry, oxygen-free nitrogen atmosphere using standard Schlenk techniques. Solvents were purified by a MB SPS- 800 purification system. All starting materials were obtained from commercial sources and used without further purification. $\mathrm{N}, \mathrm{N}$-dimethylformamide (Sigma Aldrich, anhydrous, 99.8\%) and the supporting electrolyte $\mathrm{NBu}_{4} \mathrm{PF}_{6}$ was purchased from Fluka (puriss., electrochemical grade). ${ }^{1} \mathrm{H}$ NMR spectra were recorded on a Bruker GPX (400 MHz) spectrometer and were referenced to the resonances of the solvent used $\left(\mathrm{CDCl}_{3}\right.$ and DMSO- $\left.d_{6}\right)$. UVvis absorption spectra were recorded using Specord 205 UV-visNIR spectrophotometer with quartz cuvettes of $1 \mathrm{~cm}$ pathlength. HRMS were recorded on a Water Q-TOF mass spectrometer (details: source ESI, acetone as solvent) at the corresponding facilities of the CRMPO, "Centre Régional de Mesures Physiques de l'Ouest, Université de Rennes 1". Molecular modelling calculations were performed using PM3Spartan molecular modelling program.

\subsection{Materials synthesis}

Synthesis of 5,10,15,20-tetraphenyl-21H,23H-porphine (TPP). It was prepared according to literature procedure. ${ }^{23}$

Synthesis of 5,10,15,20-tetraphenyl-21H,23H-porphine iron(III) chloride (1). It was prepared as previously described. ${ }^{24}$ A pre-dried $100 \mathrm{~mL}$ Schlenk flask was equipped with a magnetic stirring bar. The flask was charged with tetraphenylporphyrin (TPP) $(0.11 \mathrm{~g}, 0.18 \mathrm{mmol}), \mathrm{FeCl}_{2} \cdot 4 \mathrm{H}_{2} \mathrm{O}(0.32 \mathrm{~g}, 1.6 \mathrm{mmol})$ and DMF $(20 \mathrm{~mL})$. The reaction mixture was refluxed for $4 \mathrm{~h}$. After cooling down, the solvent was evaporated, and the crude was washed with water until the water phase became colourless. The solid was taken with $\mathrm{CH}_{2} \mathrm{Cl}_{2}$, dried with $\mathrm{MgSO}_{4}$ followed by solvent evaporation giving $0.10 \mathrm{~g}$ (81\% yield) of 1 after drying under vacuum. ${ }^{1} \mathrm{H} \mathrm{NMR}\left(400 \mathrm{MHz}, \mathrm{CDCl}_{3}\right): \delta=79.9,13.4,12.2$, $6.4 \mathrm{ppm} . \lambda_{\mathrm{abs}} / \mathrm{nm}$ (DMF), $\left(\varepsilon / 10^{3} \mathrm{M}^{-1} \mathrm{~cm}^{-1}\right): 416$ (96.4), 513 (11.9), 573 (12.4). The data match those found in the literature. ${ }^{25}$

Synthesis of 4,4',4",4"'-(iron(III)porphine-5,10,15,20-tetrayl)-tetrakis(methyl benzoate) chloride (2'). Distilled pyrrole $(0.35$ $\mathrm{mL}, 5.0 \mathrm{mmol}$ ) and methyl 4-formylbenzoate (0.827 g, 5.0 $\mathrm{mmol}$ ) were added to a pre-dried $250 \mathrm{~mL}$ flask containing propionic acid $(25 \mathrm{~mL})$. The reaction mixture was covered with aluminum foil and the reaction mixture was refluxed overnight at $140{ }^{\circ} \mathrm{C}$. After cooling down to room temperature, the resulting purple crystals were filtered and washed with water and then dissolved in dichloromethane. The organic layer was dried with $\mathrm{MgSO}_{4}$ followed by solvent evaporation affording a crude that was purified by column chromatography with dichloromethane and petroleum ether (33:67 to 90:10). The fraction containing 4,4',4", 4'"'-(porphine-5,10,15,20-tetrayl)te-trakis(methyl benzoate) (2") was dried under vacuum (0.19 g, $17 \%$ yield). ${ }^{1} \mathrm{H}$ NMR $\left(400 \mathrm{MHz}, \mathrm{CDCl}_{3}\right): \delta=8.87(\mathrm{~s}, 8 \mathrm{H}), 8.49(\mathrm{~d}$, $J=8.1,8 \mathrm{H}), 8.33(\mathrm{~d}, J=8.1,8 \mathrm{H}), 4.15(\mathrm{~s}, 12 \mathrm{H}),-2.74(\mathrm{~s}, 2 \mathrm{H})$ $\mathrm{ppm}$. The data match those found in the literature. ${ }^{26} \mathrm{~A}$ pre-dried $100 \mathrm{~mL}$ Schlenk flask was equipped with a magnetic stirring bar. The flask was charged with 2"' $(0.19 \mathrm{~g}, 0.33 \mathrm{mmol}), \mathrm{FeCl}_{2} \cdot 4 \mathrm{H}_{2} \mathrm{O}$ $(0.80 \mathrm{~g}, 4.2 \mathrm{mmol})$ and DMF $(21.8 \mathrm{~mL})$. The reaction mixture was 
refluxed for $4 \mathrm{~h}$. After cooling down, the solvent was evaporated, and the solid was washed with water until the water phase became colourless. Then, the crude was dissolved in $\mathrm{CH}_{2} \mathrm{Cl}_{2}$, dried with $\mathrm{MgSO}_{4}$ followed by solvent evaporation. 2' was obtained $\left(0.14 \mathrm{~g}, 70 \%\right.$ yield) after drying under vacuum. ${ }^{1} \mathrm{H}$ NMR (400 MHz, $\left.\mathrm{CDCl}_{3}\right): \delta=80.4,14.0,12.9 \mathrm{ppm} . \lambda_{\mathrm{abs}} / \mathrm{nm}$ (DMF), $\left(\varepsilon / 10^{3} \mathrm{M}^{-1} \mathrm{~cm}^{-1}\right): 428$ (109), 520 (7.25), 571 (8.47). The data match those found in the literature. ${ }^{26}$

Synthesis of 4,4',4",4'"'-(iron(III)porphine-5,10,15,20-tetrayl)tetrakis(benzoic acid) chloride (2). Porphyrin 2' (0.090 g, 0.096 $\mathrm{mmol}$ ) and $\mathrm{LiOH}(0.47 \mathrm{~g}, 19 \mathrm{mmol})$ were added to a mixture of 1,4-dioxane/water $(24 \mathrm{~mL}, 7: 1 \mathrm{v} / \mathrm{v})$. Then, the reaction mixture was refluxed for $16 \mathrm{~h}$ at $105^{\circ} \mathrm{C}$. After cooling down, 1,4-dioxane was evaporated followed by acidification with $1 \mathrm{M} \mathrm{HCl}$ until full precipitation. After filtration and drying under vacuum, 2 was obtained quantitatively (70 mg, $99 \%$ yield). ${ }^{1} \mathrm{H}$ NMR $(400 \mathrm{MHz}$, DMSO- $\left.d_{6}\right): \delta=74.1,13.8,10.0 \mathrm{ppm}$. $\lambda_{\text {abs }} / \mathrm{nm}$ (DMF), $\left(\varepsilon / 10^{3} \mathrm{M}^{-1}\right.$ $\mathrm{cm}^{-1}$ ): 415 (28.8), 522 (6.52), 571 (4.55). HRMS (ESI) calcd. for [M-Cl] ${ }^{+} \mathrm{C}_{48} \mathrm{H}_{28} \mathrm{~N}_{4} \mathrm{O}_{8}{ }^{56} \mathrm{Fe} 844.1251$, found 844.1249 (0 ppm). HRMS (ESI) calcd. for $\left[\mathrm{M}-\mathrm{Cl}+\mathrm{CH}_{3} \mathrm{COCH}_{3}\right]^{+} \mathrm{C}_{51} \mathrm{H}_{34} \mathrm{~N}_{4} \mathrm{O}_{9}{ }^{56} \mathrm{Fe}$ 902.1670, found 902.1658 (1 ppm). The data match those found in the literature. ${ }^{27}$

Synthesis of 3,3',3", 3'"'-(iron(III)porphine-5,10,15,20-tetrayl)tetrakis(methyl benzoate) chloride (3'). Distilled pyrrole $(0.35$ $\mathrm{mL}, 5.0 \mathrm{mmol}$ ) and methyl 3-formylbenzoate $(0.827 \mathrm{~g}, 5.0$ mmol) were added to a pre-dried $250 \mathrm{~mL}$ flask containing propionic acid $(25 \mathrm{~mL})$. The reaction mixture was covered with aluminum foil and the reaction mixture was refluxed overnight at $140^{\circ} \mathrm{C}$. After cooling down to room temperature, the resulting purple crystals were filtered and washed with water then dissolved in dichloromethane. The organic layer was dried with $\mathrm{MgSO}_{4}$ followed by solvent evaporation. The crude mixture was purified by column chromatography $\left(\mathrm{SiO}_{2}, \mathrm{CH}_{2} \mathrm{Cl}_{2}\right.$ :heptane, $8: 2$ to $9: 1 \mathrm{v} / \mathrm{v}$ ). The fraction containing the expected product was evaporated and dried under vacuum affording $3,3^{\prime}, 3^{\prime \prime}, 3^{\prime \prime \prime}$ (por--phine-5,10,15,20-tetrayl)tetrakis(methyl benzoate) (3") as purple crystals $\left(0.20 \mathrm{~g}, 19 \%\right.$ yield). ${ }^{1} \mathrm{H}$ NMR $\left(400 \mathrm{MHz}, \mathrm{CDCl}_{3}\right)$ : $\delta=8.92(\mathrm{~s}, 4 \mathrm{H}), 8.82(\mathrm{~s}, 8 \mathrm{H}), 8.52(\mathrm{~d}, J=8 \mathrm{~Hz}, 4 \mathrm{H}), 8.43(\mathrm{~d}, J=$ $8 \mathrm{~Hz}, 4 \mathrm{H}), 7.88(\mathrm{t}, J=7.6 \mathrm{~Hz}, 4 \mathrm{H}), 4.02(\mathrm{~s}, 12 \mathrm{H}),-2.77(\mathrm{~s}, 2 \mathrm{H})$ $\mathrm{ppm}$. The data match those found in the literature. ${ }^{26} \mathrm{~A}$ pre-dried $100 \mathrm{~mL}$ Schlenk flask was equipped with a magnetic stirring bar. The flask was charged with 3" (0.43 g, $0.50 \mathrm{mmol}), \mathrm{FeCl}_{2} \cdot 4 \mathrm{H}_{2} \mathrm{O}$ $(1.24 \mathrm{~g}, 6.5 \mathrm{mmol})$ and DMF $(30 \mathrm{~mL})$. The reaction mixture was refluxed for $4 \mathrm{~h}$. After cooling down, the solvent was evaporated under vacuum, and the crude was washed with water until the solution turned colourless. Then, the solid was dissolved in $\mathrm{CH}_{2} \mathrm{Cl}_{2}$, dried with $\mathrm{MgSO}_{4}$ followed by solvent evaporation. 3' was obtained after drying under vacuum (0.42 g, 99\% yield). ${ }^{1} \mathrm{H}$ NMR (400 MHz, $\left.\mathrm{CDCl}_{3}\right): \delta=80.3,13.3,12.2,8.39,7.72 \mathrm{ppm}$. $\lambda_{\text {abs }} / \mathrm{nm}$ (DMF), $\left(\varepsilon / 10^{3} \mathrm{M}^{-1} \mathrm{~cm}^{-1}\right): 424$ (92.6), 520 (7.59), 569 (11.2). The data match those found in the literature. ${ }^{26}$

Synthesis of 3,3',3', 3'”'-(iron(III)porphine-5,10,15,20-tetrayl)-tetrakis(benzoic acid) chloride (3). Porphyrin 3' (0.260 g, 0.28 $\mathrm{mmol}$ ) and $\mathrm{LiOH}(1.32 \mathrm{~g}, 55 \mathrm{mmol})$ were added to a mixture of 1,4-dioxane/water (68 mL, 1,4-dioxane:water, 7:1 v/v). Then, the reaction mixture was refluxed for $16 \mathrm{~h}$ at $105^{\circ} \mathrm{C}$. After cooling down, 1,4-dioxane was evaporated followed by acidification with $1 \mathrm{M} \mathrm{HCl}$ until full precipitation. After filtration and drying under vacuum, 3 was quantitatively obtained $(0.24$ mg, 99\%). ${ }^{1} \mathrm{H}$ NMR (400 MHz, DMSO- $d_{6}$ ): $\delta=80.3,13.6,13.3$, $12.2 \mathrm{ppm}$. HRMS-ESI calcd for $\mathrm{C}_{48} \mathrm{H}_{28} \mathrm{FeN}_{4} \mathrm{O}_{8}[\mathrm{M}-\mathrm{Cl}]^{+}:$: 844.12565, found 844.1249 (0 ppm). $\lambda_{\text {abs }} / \mathrm{nm}$ (DMF), $\left(\varepsilon / 10^{3} \mathrm{M}^{-1} \mathrm{~cm}^{-1}\right): 416$ (62.4), 522 (5.51), 573 (5.26). HRMS (ESI) calcd. for [M-Cl] ${ }^{+}$ $\mathrm{C}_{48} \mathrm{H}_{28} \mathrm{~N}_{4} \mathrm{O}_{8}{ }^{56} \mathrm{Fe} 844.1251$, found 844.1249 (0 ppm). HRMS (ESI) calcd. for $\left[\mathrm{M}-\mathrm{Cl}+\mathrm{CH}_{3} \mathrm{COCH}_{3}\right]^{+} \mathrm{C}_{51} \mathrm{H}_{34} \mathrm{~N}_{4} \mathrm{O}_{9}{ }^{56} \mathrm{Fe}$ 902.1670, found 902.1658 (1 ppm).

Synthesis of 2,2',2",2'"'-(iron(III)porphine-5,10,15,20-tetrayl)-tetrakis(methyl benzoate) chloride (4'). Distilled pyrrole $(0.35$ $\mathrm{mL}, 5.0 \mathrm{mmol})$ and methyl 2-formylbenzoate $(0.70 \mathrm{~mL}, 5.0$ $\mathrm{mmol}$ ) were added to dichloromethane $(500 \mathrm{~mL})$ in a pre-dried flask under argon bubbling for 20 minutes. $\mathrm{BF}_{3} \cdot \mathrm{Et}_{2} \mathrm{O}(0.31 \mathrm{~mL}$, $2.50 \mathrm{mmol}$ ) was added and the reaction mixture was stirred for $2 \mathrm{~h}$ at room temperature with light protection. Then, 2,3dichloro-5,6-dicyano-p-benzoquinone ( $D D Q, 1.13 \mathrm{~g}, 5.0 \mathrm{mmol}$ ) was added to the reaction mixture and continued stirring for 1 $\mathrm{h}$ at room temperature. After that, triethylamine was added to the mixture, and the solvent was evaporated under reduced pressure. The residue was filtrated over silica with a mixture of methanol and dichloromethane $(1: 99, v / v)$. The solid was further purified by column chromatography with dichloromethane and petroleum ether $(1: 2$ to $9: 1, v / v)$. The fraction containing 2,2',2", 2'"'-(porphine-5,10,15,20-tetrayl)te-trakis(methyl benzoate) (4") was dried under vacuum affording the expected mixture of four atropisomers as purple crystals (0.40 g, 38\% yield). ${ }^{1} \mathrm{H}$ NMR $\left(400 \mathrm{MHz}, \mathrm{CDCl}_{3}\right): \delta=8.65-7.59(\mathrm{~m}$, $24 \mathrm{H}), 2.89(\mathrm{~s}, 3 \mathrm{H}), 2.78(\mathrm{~s}, 3 \mathrm{H}), 2.73(\mathrm{~s}, 3 \mathrm{H}), 2.61(\mathrm{~s}, 3 \mathrm{H}),-2.42$ $(\mathrm{s}, 2 \mathrm{H}) \mathrm{ppm}$. The data match those found in the literature. ${ }^{26} \mathrm{~A}$ pre-dried $100 \mathrm{~mL}$ schlenk flask was equipped with a magnetic stirring bar. The flask was charged with 4"' $(0.16 \mathrm{~g}, 0.19 \mathrm{mmol})$, $\mathrm{FeCl}_{2} \cdot 4 \mathrm{H}_{2} \mathrm{O}(0.47 \mathrm{~g}, 2.4 \mathrm{mmol})$ and DMF $(20 \mathrm{~mL})$. The reaction mixture was refluxed for 3-4 $\mathrm{h}$. After cooling down, the solvent was evaporated under vacuum, and the crude was washed with water until the solution turned colourless. Then, the crude was dissolved in $\mathrm{CH}_{2} \mathrm{Cl}_{2}$, dried with $\mathrm{MgSO}_{4}$ followed by solvent evaporation. 4' was quantitatively obtained after drying under vacuum $(0.18 \mathrm{~g}, 99 \%) .{ }^{1} \mathrm{H} \mathrm{NMR}\left(400 \mathrm{MHz}, \mathrm{CDCl}_{3}\right): \delta=80.4,14.4$, 13.7, 13.5, 12.4. $\lambda_{\mathrm{abs}} / \mathrm{nm}$ (DMF), $\left(\varepsilon / 10^{3} \mathrm{M}^{-1} \mathrm{~cm}^{-1}\right): 421$ (78.1), 519 (7.25), 577 (6.62). The data match those found in the literature. ${ }^{26}$

Synthesis of 2,2',2",2'"'-(iron(III)porphine-5,10,15,20-tetrayl)-tetrakis(benzoic acid) chloride (4). Porphyrin 4' (0.166 g, 0.177 $\mathrm{mmol}$ ) and LiOH (1.557 g, $65 \mathrm{mmol}$ ) were added to a mixture of 1,4-dioxane/water (68 mL, 1,4-dioxane:water, 7:1 v/v). Then, the reaction mixture was refluxed for $16 \mathrm{~h}$ at $105^{\circ} \mathrm{C}$. After cooling down, 1,4-dioxane was evaporated followed by acidification with $1 \mathrm{M} \mathrm{HCl}$ until full precipitation. After filtration and drying under vacuum, 4 was quantitatively obtained $(0.158$ g, 99\%). ${ }^{1} \mathrm{H}$ NMR (400 MHz, DMSO- $\left.d_{6}\right): \delta=73.4,10.1,9.7,9.3$. $\lambda_{\text {abs }} / \mathrm{nm}$ (DMF), $\left(\varepsilon / 10^{3} \mathrm{M}^{-1} \mathrm{~cm}^{-1}\right): 426$ (17.5), 515 (2.64), 573 (1.42). HRMS (ESI) calcd. for [M-Cl] ${ }^{+} \mathrm{C}_{48} \mathrm{H}_{28} \mathrm{~N}_{4} \mathrm{O}_{8}{ }^{56} \mathrm{Fe} 844.1251$, found 844.1249 (0 ppm). HRMS (ESI) calcd. for [M$\left.\mathrm{Cl}+\mathrm{CH}_{3} \mathrm{COCH}_{3}\right]^{+} \mathrm{C}_{51} \mathrm{H}_{34} \mathrm{~N}_{4} \mathrm{O}_{9}{ }^{56} \mathrm{Fe}$ 902.1670, found 902.1658 (1 ppm). The data match those found in the literature. ${ }^{16}$

4.3. Electrochemical study 
Cyclic Voltammetry. Cyclic voltammograms (CVs) were recorded in a home-made three neck cell with a gas inlet. The working electrode was a $3 \mathrm{~mm}$-diameter glassy carbon $(\mathrm{CH}$ Instrument) disk carefully polished using decreasing size of diamond paste (from 15 to $1 \mu \mathrm{m}$ ), ultrasonically cleaned in ultrapure water and dried before use. The counter-electrode was a graphite rod and the reference electrode was a $\mathrm{KCl}$ saturated calomel electrode (SCE). All experiments were carried out under argon atmosphere at room temperature, CVs were obtained with a SP 150 (Bio-Logic) potentiostat. The CVs were recorded at $100 \mathrm{mV} \mathrm{s}^{-1}$. Unless specified, the ohmic drop was uncompensated. Catalytic onset potentials ( $\left.E_{\text {onset }}\right)$ were determined at the beginning of the HER curve $(i=5 \mu \mathrm{A})$ at a concentration of proton source of $10 \mathrm{mM}$.

\subsection{Bulk electrolysis and faradaic efficiency}

Bulk Electrolysis. The experiments were carried out in a Hoffman cell with a glassy carbon rod (the active surface area was $5 \mathrm{~cm}^{2}$ ) as the working electrode, SCE as the reference electrode, and graphite as a counter electrode, respectively. The cell contained $20 \mathrm{~mL}$ of $0.5 \mathrm{mM}$ iron porphyrin, $15 \mathrm{mM}$ $\mathrm{Et}_{3} \mathrm{NHCl}$, and $0.1 \mathrm{M} \mathrm{Bu}_{4} \mathrm{NPF}_{6}$ in DMF. The electrolysis solution was purged with argon for 30 minutes, prior to electrolysis measurements. The solution resistance was compensated by the potentiostat (measured as the impedance at high frequency). A CV was first recorded, and the controlledpotential electrolysis was performed at a potential slightly more negative than the catalytic onset potential. After 1 hour, the electrolysis was stopped and the volume of produced gas was measured.

Faradaic Efficiency Calculation. The HER Faradaic efficiency $(\eta)$ was calculated by dividing the measured number of moles of $\mathrm{H}_{2}$ produced $\left(n_{\mathrm{H} 2 \exp }\right)$ by the theoretical amount of $\mathrm{H}_{2}\left(n_{\mathrm{H} 2 \mathrm{th}}\right)$ expected on the basis of the charge $(Q)$ consumed during the controlled-potential electrolysis measurements, calculated following equation (1):

$$
n_{H_{2} t h}=\frac{Q}{2 F}
$$

The experimental number of moles of hydrogen was determined using the measured volume of produced gas in the cathodic compartment of the Hoffman cell, that was converted in number of moles using the perfect gas law.

4.5. UV-vis titration studies of 1-4 and 2'-4' with $\mathrm{Et}_{3} \mathrm{NHCl}$. General procedure for UV-vis titrations. Host-guest interactions in solution were studied by UV-vis spectroscopy. Solution of each molecule $\left(10^{-6} \mathrm{M}\right.$ except $10^{-5} \mathrm{M}$ for 4 ) was prepared using $\mathrm{N}, \mathrm{N}$ dimethylformamide as a solvent. Increasing number of $\mathrm{Et}_{3} \mathrm{NHCl}$ equivalents were added to the solution of each molecule $(1.5 \mathrm{~mL}$ in a $1 \mathrm{~cm}$-pathlength quartz cell). The host concentration was kept constant. This study enabled us to qualitatively evidence the interaction between the molecule and ammonium salt $\left(\mathrm{Et}_{3} \mathrm{NHCl}\right)$. Note that the data was not accurate enough to determine binding constants probably due to the presence of traces of water.

\section{Conflicts of interest}

There are no conflicts to declare.

\section{Acknowledgements}

CNRS, Université de Rennes 1, Rennes Métropole and Institut des Sciences Chimiques de Rennes ("Projet inter-Equipe") are acknowledged for financial support. S.K. acknowledges Foundation Rennes 1, French Embassy in Thailand and Campus France for a Mastership grant. Dr. J. Rault-Berthelot is acknowledged for valuable discussions and C. Valter-Potier for making the Hoffman cell.

\section{Notes and references}

1 (a) N. S. Lewis and D. G. Nocera, Proc. Natl. Acad. Sci., 2006, 103, 15729-15735; (b) M. R. Shaner, H. A. Atwater, S. Lewis and E. W. A. Mcfarland, Energy Environ. Sci., 2016, 9, 23542371.

2 (a) A. Fujishima and K. Honda, Nature, 1972, 238, 37-38; (b) A. J. Nozik, Appl. Phys. Lett., 1976, 29, 150-153; (c) M. G. Walter, E. L. Warren, J. R. McKone, S. W. Boettcher, Q. Mi, E. A. Santori and N. S. Lewis, Chem. Rev., 2010, 110, 6446-6473; (d) D. G. Nocera, Acc. Chem. Res., 2012, 45, 767-776; (e) J. W. Ager, M. R. Shaner, K. A. Walczak, I. D. Sharp and S. Ardo, Energy Environ. Sci., 2015, 8, 2811-2824; (f) K. Sivula and R. van de Krol, Nat. Rev. Mater., 2016, 1, 15010.

3 J. O. Bockris, Science, 1972, 176, 1323.

4 (a) D. Kang, T. W. Kim, S. R. Kubota, A. C. Cardiel, H. G. Cha and K.-S. Choi, Chem. Rev., 2015, 115, 12839-12887; (b) C. Ding, J. Shi, Z. Wang and C. Li, ACS Catal., 2017, 7, 675-688.

5 (a) S. Trasatti, J. Electroanal. Chem. Interfacial Electrochem., 1972, 39, 163-184; (b) C. C. L. McCrory, S. Jung, I. M. Ferrer, S. M. Chatman, J. C. Peters and T. F. Jaramillo, J. Am. Chem. Soc., 2015, 137, 4347-4357; (c) C. G. Morales-Guio, L.-A. Stern and X. Hu, Chem. Soc. Rev., 2014, 43, 6555-6569.

6 (a) M. R. DuBois and D. L. DuBois, Chem. Soc. Rev., 2009, 38, 62-72; (b) W. Zhang, W. Lai and R. Cao, Chem. Rev., 2017, 117, 3717-3797; (c) V. Artero, Nat. Energy, 2017, 2, 17131.

7 (a) P.-A. Jacques, V. Artero, J. Pécaut and M. Fontecave, Proc. Natl. Acad. Sci., 2009, 106, 20627-20632; (b) M. L. Helm, M. P. Stewart, R. M. Bullock, R. M. DuBois and D. L. DuBois, Science, 2011, 333, 863-866; (c) V. Artero, M. Chavarot-Kerlidou and M. Fontecave, Angew. Chem. Int. Ed., 2011, 50, 7238-7266; (d) M. J. Rose, H. B. Gray and J. R. Winkler, J. Am. Chem. Soc., 2012, 134, 8310-8313; (e) C. C. L. McCrory, C. Uyeda and J. C. Peters, J. Am. Chem. Soc., 2012, 134, 3164-3170.

8 R. M. Kellett and T. G. Spiro, Inorg. Chem., 1985, 24, 23732377.

9 I. Bhugun, D. Lexa and J.-M. Savéant, J. Am. Chem. Soc., 1996, 118, 3982-3983.

10 D. K. Bediako, B. H. Solis, D. K. Dogutan, M. M. Roubelakis, A. G. Maher, C. H. Lee, M. B. Chambers, S. Hammes-Schiffer and D. G. Nocera, Proc. Natl. Acad. Sci., 2014, 111, 15001-15006.

11 J. Jiang, K. L. Materna, S. Hedström, K. R. Yang, R. H. Crabtree, V. S. Batista and G. W. Brudvig, Angew. Chem. Int. Ed., 2017, 56, 9111-9115.

12 (a) Z. Liu, A. A. Yasseri, J. S. Lindsey and D. F. Bocian, Science, 2003, 302, 1543-1545; (b) A. Maurin and M. Robert, J. Am. Chem. Soc., 2016, 138, 2492-2495; (c) I. Hod, M. D. Sampson, P. Deria, C. P. Kubiak, O. K. Farha and J. T. Hupp, ACS Catal., 2015, 5, 6302-6309.

13 (a) Y. Han, H. Fang, H. Jing, H. Sun, H. Lei, W. Lai and R. Cao, Angew. Chem. Int. Ed., 2016, 55, 5457-5462; (b) N. Wang, H. 
Lei, Z. Zhang, J. Li, W. Zhang and R. Cao, Chem. Sci., 2019, DOI: 10.1039/c8sc05247f.

14 Z.-Y. Wu, T. Wang, Y.-S. Meng, Y. Rao, B.-W. Wang, J. Zheng, S. Gao and J.-L. Zhang, Chem. Sci., 2017, 8, 5953-5961.

15 (a) C. H. Lee, D. K. Dogutan and D. G. Nocera, J. Am. Chem. Soc., 2011, 133, 8775-8777; (b) B. H. Solis, A. G. Maher, T. Honda, D. C. Powers, D. G. Nocera and S. Hammes-Schiffer, ACS Catal., 2014, 4, 4516-4526; (c) M. M. Roubelakis, D. K. Bediako, D. K. Dogutan and D. G. Nocera, Energy Environ. Sci., 2012, 5, 7737-7740; (d) B. H. Solis, A. G. Maher, D. K. Dogutan, D. G. Nocera and S. Hammes-Schiffer, Proc. Natl. Acad. Sci., 2016, 113, 485-492.

16 C. T. Carver, B. D. Matson and J. M. Mayer, J. Am. Chem. Soc., 2012, 134, 5444-5447.

17 C. Costentin, S. Drouet, M. Robert and J.-M. Savéant, Science, 2012, 338, 90-94.

18 (a) R. S. Nicholson and I. Shain, Anal. Chem., 1964, 36, 706723. (b) R, S, Nicholson, Anal. Chem., 1965, 37, 1351-1355.

19 (a) C. Costentin, S. Drouet, M. Robert and J.-M. Savéant, J. Am. Chem. Soc., 2012, 134, 11235-11242; (b) D. J. Graham and D. G. Nocera, Organometallics, 2014, 33, 4994-5001.

20 (a) Y. Marcus and G. Hefter, Chem. Rev., 2006, 106, 45854621. (b) A. Macchioni, Chem. Rev., 2005, 105, 2039-2073. (c) D. J. Barlow and J. M. Thornton, J. Mol. Biol. 1983, 168, 867885.

21 C. Costentin, H. Dridi and J.-M. Saveant, J. Am. Chem. Soc., 2014, 136, 13727-13734

22 D. Lexa, P. Rentien, J.-M. Saveant and F. Xu, J. Electroanal. Chem., 1985, 191, 253-279.

23 J. S. Lindsey, I. C. Schreiman, H. C. Hsu, P. C. Kearney and A. M. Marguerettaz, J. Org. Chem., 1987, 52, 827-836.

24 A. F. Walker and G. N. Mar, Ann. N. Y. Acad. Sci., 1973, 206, 328-348.

25 H. Jiménez, J. Moratal and B. Loock, New J. Chem., 2002, 323329.

26 R. B. Ambre, Q. Daniel, T. Fan, H. Chen, B. Zhang, L. Wang, M. S. Ahlquist, L. Duan and L. Sun, Chem. Commun., 2016, 52, 14478-14481.

27 S. E. Clarke, C. C. Wamser and H. E. Bell, J. Phys. Chem. A 2002, 106, 3235-3242.

28 I. M. Kolthoff, M. K. Chantooni Jr., H. Smagowski, Anal. Chem. 1970, 1622-1628.

TOC: The influence of ion-pair interactions between carboxycontaining iron porphyrins and the proton source in the hydrogen evolution reaction is described.

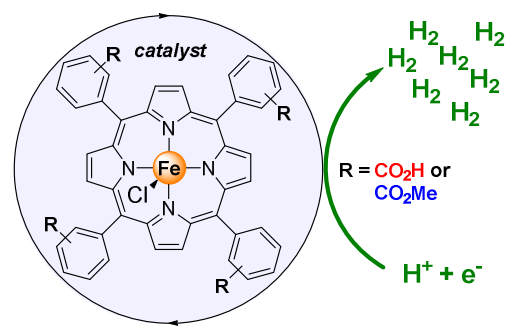

